\title{
CORPORATE SOCIAL RESPONSIBILITY AND INNOVATION: A MULTIPLE CASE STUDY WITH BRAZILIAN COMPANIES
}

\author{
Natália Rohenkohl do Canto \\ Doutoranda em Administração \\ Universidade Federal do Rio Grande do Sul Porto Alegre - RS - Brasil \\ natalia.canto@ufrgs.br https://orcid.org/0000-0001-8562-0054 \\ Andréia Cristina Dullius Verschoore \\ Mestre em Administração \\ Universidade Federal do Rio Grande do Sul Porto Alegre - RS - Brasil \\ andreiadullius@gmail.com \\ Patrícia Dias \\ Doutora em Administração \\ Universidade Federal do Rio Grande do Sul Porto Alegre - RS - Brasil \\ patricia.pdias@gmail.com \\ Marcia Dutra de Barcellos \\ Doutora em Agronegócios \\ Universidade Federal do Rio Grande do Sul Porto Alegre - RS - Brasil \\ marcia.barcellos@ufrgs.br https://orcid.org/0000-0002-4311-2921
}

\begin{abstract}
Different stakeholders pressure companies to innovate and to include Corporate Social Responsibility (CSR) in their strategy. This article examines how innovation and CSR relate in some Brazilian companies. We conducted a multiple case study with five companies that claim to be highly innovative and to include social and environmental responsibility in their strategic agenda. Results indicate that CSR is mainly employed in a reactive way and cannot be considered strategic in these cases. CSR has a secondary position for these companies, while innovation is prioritized, since it is perceived as a source of value and competitiveness. We found a unilateral relation between the constructs, according to which innovation can generate CSR benefits, but CSR does not generate benefits in terms of innovation. CSR and innovation also exist independently, in a way that not every innovation generates CSR benefits. The paper presents implications and future studies suggestions.
\end{abstract}

Key words: Brazil. Corporate social responsibility. Innovation. Strategy.

\section{A RELAÇÃO ENTRE RESPONSABILIDADE SOCIAL CORPORATIVA E INOVAÇÃO: UM ESTUDO DE CASO MÚLTIPLO COM EMPRESAS BRASILEIRAS}

\section{RESUMO}

Diferentes stakeholders pressionam as empresas a inovar e a adotar práticas de Responsabilidade Social Corporativa (RSC). Este artigo examina a relação entre inovação e RSC em empresas brasileiras. Realizamos um estudo de caso múltiplo com cinco empresas brasileiras que afirmam ser altamente inovadoras e incluir responsabilidade social e ambiental em sua pauta estratégica. Os resultados indicam que a RSC é empregada, principalmente, de maneira reativa e não pode ser considerada estratégica. A RSC ocupa uma posição secundária nas empresas estudadas, enquanto a inovação é priorizada, já que é considerada fonte de valor e competitividade. Encontramos uma relação unilateral entre os construtos, na qual a inovação pode gerar benefícios de RSC, mas a RSC não gera benefícios de inovação. A RSC e a inovação também existem independentemente, de modo que nem toda inovação gera benefícios em termos socioambientais. $\mathrm{O}$ trabalho apresenta implicações e sugestões de estudos futuros..

Palavras-chave: Brasil. Estratégia. Inovação. Responsabilidade social corporativa.

Data da submissão: $18 / 09 / 2019$

Data de aceite: $12 / 01 / 2020$

1 INTRODUCTION

Revista de Gestão Social e Ambiental - RGSA, São Paulo, v. 14, n. 1, p. 93-113, jan./abr. 2020. 
Different stakeholders pressure companies to innovate and to include Corporate Social Responsibility (CSR) in their strategy. Companies' extended role in the chain makes them invest in sustainability and in strategies that go beyond their internal operations and consider consumers and other stakeholders (Oliveira, Gomez, \& Correia, 2018). Although the adoption of socioenvironmental practices is perceived as a burden by some organizations, it also has potential advantages. For example, conscious consumers value environmentally friendly products (Lira, 2018). An advantage found in the literature is that socio-environmental practices can generate innovations, becoming strategic to the companies (Battisti \& Perry, 2011; Stigson, 2002).

However, there is actually no consensus about the relation between CSR and innovation (Ratajczak \& Szutowski, 2016). The European Commission (2011) suggests that CSR can be related to benefits such as innovations, greater competitiveness and social inclusion. Other studies question the creation of value and innovations through CSR (Bocquet, Le Bas, Mothe, \& Poussing, 2013).

In Brazil, according to a project ${ }^{1}$ conducted in Rio Grande do Sul, there is a significant number of companies that consider themselves to be highly innovative and to include social and environmental responsibility in their strategic guidelines, indicating that in these cases there could be a relationship between CSR and innovation. Considering the possible relationship between CSR and innovation, the divergence in literature about how these topics relate, as well as the growing interest in innovation and sustainability, some questions can be raised: is there a relationship between innovation and CSR? If yes, in which way? Does CSR lead to innovation, or does it happen the other way around?

This study investigates the relationship between socio-environmental practices and innovation in Brazilian companies. Taking into account the opportunity of exploring the previously mentioned companies, as well as the scarcity of studies on this topic in the Brazilian context, we proposed the following research question: how do innovation and CSR relate in Brazilian companies? We aim to investigate the innovations in the companies, to understand the CSR actions, and to understand the relationship between the topics.

We contribute to the CSR literature in several ways. The literature on the relation between CSR and innovation is scarce (Barakat \& Polo, 2016; Ratajczak \& Szutowski, 2016), with the need of additional research "[...] to develop a more nuanced understanding of the link between different types of innovation and different types of CSR practices" (García-Piqueres \& García-Ramos, 2020, p. 812). Besides, there are few empirical studies investigating the topics - and especially few with qualitative data collection and in developing countries (Ratajczak \& Szutowski, 2016). Recent empirical studies on the relation of CSR and innovations (e.g. García-Piqueres \& García-Ramos (2020) and Bocquet, Le Bas, Mothe, and Poussing (2017)) focus on the European context. We address these gaps by investigating the relation of CSR and innovation in a qualitative study with Brazilian companies. The paper also contributes to the more recent view of CSR, according to which "[...] there is a conceptual shift from financial outcomes to non-financial, social, and organizational outcomes" (Wang, Tong, Takeuchi, \& George, 2016, p. 536). Therefore, both scholars and practitioners can benefit from the results.

This article is organized as follows. Section 2 presents the theoretical background. Section 3 introduces the methodological procedures, followed by the results and discussion in section 4 . Section 5 presents final remarks.

\section{THEORETICAL BACKGROUND}

${ }^{1}$ Notice $08 / 2009$ - Fapergs/CNPq - Pronex

Revista de Gestão Social e Ambiental - RGSA, São Paulo, v. 14, n. 1, p. 93-113, jan./abr. 2020. 
This section reviews innovation (section 2.1), CSR (section 2.2) and the relation between the topics (section 2.3).

\subsection{Innovation}

Innovation refers to the employment of new or significantly improved products (goods or services), processes, marketing methods, or organizational methods in business practices, workplace organization or external relations (Organisation for Economic Co-operation and Development (Oecd), 2005). The concept has been related to an increase in the competitiveness and profit generation (Forsman, 2011).

Innovation is commonly associated with formal research and development (R\&D) activities. In small businesses, this can result from daily activities, process optimization, experimentation, learning, technology adaptation, or partnerships with collaborators (Hirsch-Kreinsen, 2008b, 2008a).

There are different ways to classify innovations, as the four types (product, process, organizational and marketing) proposed by the Oecd (2005); the impact (radical or incremental) (De Jong \& Marsili, 2006; Forsman \& Annala, 2011); and the level of occurrence (enterprise, market, and worldwide) (Oecd, 2005). Besides, there may be different reasons to innovate, as competition, the pursuit of new markets, of better efficiency, or quality of products and services (Oecd, 2005). When a company innovates, it embraces a proactive attitude, seeking to meet and understand customers' needs (Hernández-Espallardo \& Delgado-Ballester, 2009), which can be catalyzed by interorganizational collaboration (Gruenberg-Bochard \& Kreis-Hoyer, 2009). Interaction plays a key role in small businesses, especially concerning $\mathrm{R} \& \mathrm{D}$, knowledge exchange, trading and marketing activities (Oecd, 2005).

Different factors can constrain the innovative capacity of businesses, as the lack of qualified personnel or awareness of norms and regulations. Sector differences can also affect the development of innovations (Hernández-Espallardo \& Delgado-Ballester, 2009; Pavitt, 1984).

\subsection{Corporate Social Responsibility}

Corporate Social Responsibility (CSR) refers to "[...] a concept whereby companies integrate social and environmental concerns in their business operations and in their interaction with their stakeholders on a voluntary basis" (European Commission, 2001, p. 5). According to the ISO 26000 guidance on Social Responsibility, CSR is a way of reaching sustainable development through the adoption of transparent and ethical behaviors that consider the expectations of stakeholders, comply with laws and international norms and are integrated and practiced in the organization and in its relationships (International Organization for Standardization, 2010).

The application of the CSR concept varies according to different factors, as company size and sector (Bocquet \& Mothe, 2011). In terms of size, larger companies usually have a broader approach towards CSR, targeting financial returns (Bocquet \& Mothe, 2011). Small and mediumsized companies (SMEs) generally invest in internal and local CSR practices, based on trust and personal commitment (Bocquet \& Mothe, 2011). The social dimension of the CSR - focusing on employees' health and well-being and on job opportunities - is the most emphasized in SMEs (Bocquet \& Mothe, 2011; Murillo \& Lozano, 2006).

It may be hard for SMEs to understand CSR concepts and how they can generate competitive advantage and economic results (Murillo \& Lozano, 2006). This lack of understanding, combined with non-formalized CSR practices and the organizational culture of SME can impose challenges to implement and measure CSR in smaller companies (Murillo \& Lozano, 2006; Vo, 2011). Faced with these difficulties, some countries propose specific requirements for CSR in

Revista de Gestão Social e Ambiental - RGSA, São Paulo, v. 14, n. 1, p. 93-113, jan./abr. 2020. 
SMEs and also create associations to help them to deal with environmental regulations (Bocquet \& Mothe, 2011; Vo, 2011).

The industrial sector also influences the adoption of CSR practices, especially in smaller companies (Bocquet \& Mothe, 2011). Companies operating in sectors in which environmental and social aspects are determinants of competitiveness, for example, have a greater tendency to find opportunities within CSR (Bocquet \& Mothe, 2011). Besides, some sectors make companies more or less susceptible to pressures from different groups in regard to social and environmental issues (Bocquet \& Mothe, 2011).

While some companies are more reactive towards CSR, behaving as a "good corporate citizen" and being concerned with the harmful effects of their activities, others employ it strategically (Battisti \& Perry, 2011; Porter \& Kramer, 2006). Strategic CSR is a key element of differentiation, that can be guided by the creation of shared value for the company and the society (Porter \& Kramer, 2006). For Burke and Logsdon (1996), to be strategic, CSR should generate business-related advantages. They propose five strategic dimensions (Illustration 1) to identify whether CSR is tightly linked to the company's strategy and a source of value creation.

Illustration 1: CSR strategic dimensions

\begin{tabular}{|c|c|c|}
\hline Dimension & Description & Examples \\
\hline Centrality & $\begin{array}{l}\text { How CSR fits in the mission and } \\
\text { goals of the company. CSR programs } \\
\text { related to the company's activities } \\
\text { are more central than philanthropy } \\
\text { programs. }\end{array}$ & $\begin{array}{l}\text { - Computer donations by computer manufacturers } \\
\text { - Engineering research fellowships } \\
\text { - New or reformulated 'green' products } \\
\text { - Process innovation, especially related to pollution } \\
\text { - Favorable change in economic or social regulations }\end{array}$ \\
\hline Specificity & $\begin{array}{l}\text { The ability to capture and internalize } \\
\text { the benefits of CSR, generating } \\
\text { competitive advantages. }\end{array}$ & $\begin{array}{l}\text { - Employee benefits: health/wellness; day care; flex-time } \\
\text { - Patent or innovation edge in product or process } \\
\text { development } \\
\text { - Energy savings }\end{array}$ \\
\hline Proactivity & $\begin{array}{l}\text { The degree of planning and } \\
\text { anticipation of CSR practices in } \\
\text { relation to economic, technological, } \\
\text { social, or political trends and in the } \\
\text { absence of crisis. }\end{array}$ & $\begin{array}{l}\text { - New or uncommon employee benefits } \\
\text { - Learning curve advantages in environment } \\
\text { management } \\
\text { - Pre-positioning for changes in regulations } \\
\text { - Environmental scanning to create edge in product ideas }\end{array}$ \\
\hline Voluntarism & $\begin{array}{l}\text { Assesses whether decision-making } \\
\text { occurs in a discretionary manner, } \\
\text { without being externally imposed by } \\
\text { compliance requirements. }\end{array}$ & $\begin{array}{l}\text { - Community support } \\
\text { - Employee loyalty and morale } \\
\text { - Positive relations with regulators } \\
\text { - Exceeding minimum standards for quality or safety }\end{array}$ \\
\hline Visibility & $\begin{array}{l}\text { The disclosure of company's } \\
\text { activities and its ability to gain } \\
\text { recognition from internal and } \\
\text { external stakeholders. }\end{array}$ & $\begin{array}{l}\text { - Employee benefit programs } \\
\text { - Public relations and/or marketing advantage } \\
\text { - First-to-market or leadership benefits }\end{array}$ \\
\hline
\end{tabular}

Based on the five dimensions proposed by Burke and Logsdon (1996), Bocquet et al. (2017, p. 247) characterize companies with a strategic CSR as being "intensive CSR adopters, in terms of the number and intensity of the various types of CSR practices they undertake. Their engagement in CSR is supported by clear economic objectives, defined at the firm level, and also requires various formalized practices that reflect the firm's ability to incorporate a stakeholder's objectives into its business operations". Companies with a responsive CSR "have not attained full CSR adoption, lack an asserted economic objective, do not clearly identify their stakeholders, and have not really succeeded in formalizing their CSR practices".

A more reactive posture towards CSR was found in a study analyzing the drivers of sustainability in SMEs from the leather-footwear industry in Brazil (Petrini, Back, \& dos Santos, 2017). Legislation was the only external factor that influenced all organizations, with the lack of

Revista de Gestão Social e Ambiental - RGSA, São Paulo, v. 14, n. 1, p. 93-113, jan./abr. 2020. 
government incentives being considered an inhibitor of sustainability. Results indicate that two main factors could drive companies to be more proactive: the values held by the leaders and members of the organization and the concerns for the organization's reputation.

A consequence of strategic CSR is value creation (Barakat \& Polo, 2016; Bocquet et al., 2013; Burke \& Logsdon, 1996). To Burke and Logsdon (1996), this occurs when all strategic dimensions of CSR are considered. Considering that "[...] value creation is necessarily about innovation" (Husted \& Allen, 2007, p. 597), it is possible to say that strategic CSR and innovation achieve a similar result. Next section explores the relationship between CSR and innovation.

\subsection{CSR and Innovation}

Studies have related the topics of CSR and innovation in different ways. A potential bidirectional relationship between CSR and innovation has been highlighted by some authors (Husted \& Allen, 2007; McWilliams \& Siegel, 2000; Moore \& Spence, 2006). Others point out a positive effect of CSR on innovation (García-Piqueres \& García-Ramos, 2020) and that companies can become more innovative through CSR (Hamza \& Dalmarco, 2013; Stigson, 2002). In these cases, CSR can foster product and process innovations (Nidumolu, Prahalad, \& Rangaswami, 2009; Sharma \& Vredenburg, 1998). The potential effect of CSR to promote radical technological innovations also seems possible in small companies with informal CSR (Bocquet \& Mothe, 2011).

Ratajczak and Szutowski (2016) summarized the knowledge on the relationship between CSR and innovation in a systematic review with 24 papers. They found different types of directions - CSR affecting innovation, innovation affecting CSR, CSR and innovation affecting each other, a functional relationship ${ }^{2}$, and the lack of a relationship between the concepts. Although studies found different directions in the relation between CSR and innovation, the impact of CSR on innovation was the most frequent result, with variations possibly related to the sector or company features (Ratajczak \& Szutowski, 2016).

The different relations found by Ratajczak and Szutowski (2016) may also relate with the type or characteristics of CSR and innovation, the company's strategic profile and the sector of activity - with the latest being particularly important to smaller companies (Bocquet \& Mothe, 2011). A study by García-Piqueres and García-Ramos (2020) with Spanish companies indicates a positive effect of CSR on innovation in most cases. It also found differences depending on the innovation type (product, process and organizational innovation) and the CSR dimension (economic, social, and environmental). While the economic dimension contributed more to fostering innovation, the social dimension showed mixed results, with both positive and negative effects on innovation, and the environmental dimension had a limited effect on innovation (GarcíaPiqueres \& García-Ramos, 2020).

There also seems to be a different relation between the concepts if the CSR is strategic or responsive. According to Porter and Kramer (2006, p. 80), strategic CSR has a positive impact on the firm's inclination to innovate and can become "[...] a source of opportunity, innovation, and competitive advantage". In the strategic CSR, innovation can be a driver of new combinations of resources to sustain competitive advantages (Bocquet et al., 2013) and generate more radical technological product innovations (Bocquet \& Mothe, 2011). Responsive CSR generates more incremental innovations (Bocquet \& Mothe, 2011) or can even negatively interfere and create barriers to innovation (Bocquet et al., 2013; Porter \& Kramer, 2006). Bocquet et al. (2017) investigated 213 firms in Luxembourg, showing that strategic CSR favored firms' growth through both product and process innovations, while responsive CSR had a negative effect on the probability of introducing technological innovations.

\footnotetext{
${ }^{2}$ The functional relation means that "the relationship between the two variables exists, but nothing is established in terms of direction" (Ratajczak \& Szutowski, 2016, p. 304).
} 
Corporate social responsibility and innovation: a multiple case study with brazilian companies

In this way, the relation between CSR and innovation is a topic that still requires understanding. In the review by Ratajczak and Szutowski (2016), most studies were in European countries, with none specifically investigating South America. We contribute to the literature by investigating the Brazilian context, as the next section on the methodological procedures explains.

\section{METHODOLOGICAL PROCEDURES}

We carried out a multiple case study (Yin, 2003) with five companies from different sizes and sectors, located in Rio Grande do Sul, the southernmost state of Brazil. The case study is adequate for answering "how" research questions (Yin, 2003), with multiple case studies allowing for a more precise delineation of relationships (Eisenhardt \& Graebner, 2007). The methodological procedures followed three main steps (Figure 1).

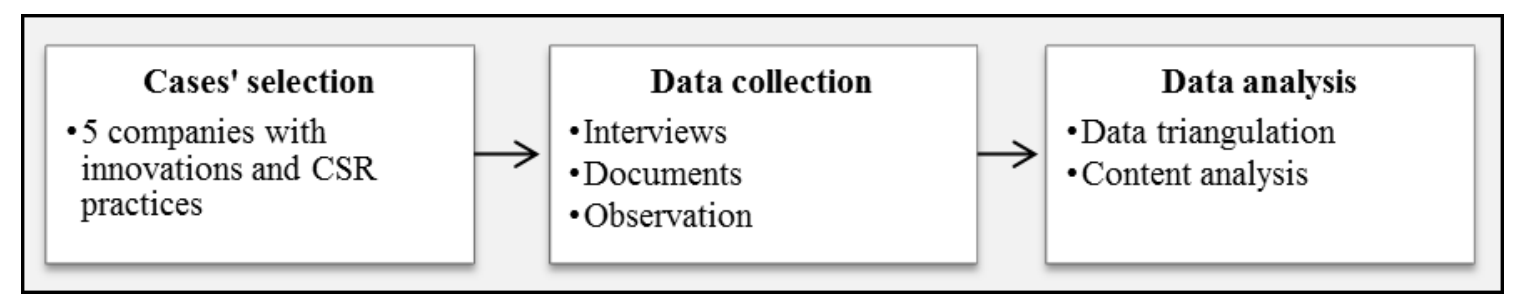

Figure 1. Methodological procedures

Source: Authors (2020)

Companies were selected according to the possibility of clarifying the relation between the two main constructs of the study (Eisenhardt \& Graebner, 2007), observing the following criteria: (1) presenting innovations; (2) including socio-environmental responsibility in their strategy; (3) accessibility. The selection of companies, as well as the collection of some data, were based on a survey of the research project "Innovation Paths of the Rio Grande do Sul Industry" - "Caminhos da Inovação da Indústria Gaúcha" (Notice 08/2009 - Fapergs / CNPq - Pronex). The research on Innovation Capabilities, applied between February and May 2014, attracted 1,331 companies (valid questionnaires from a sample of 1,470) members of the Industrial Registry of the Federation of Industries of Rio Grande do Sul (Federação das Indústrias do Estado do Rio Grande do Sul (Fiergs), 2013). Among the respondents, 51 companies considered themselves very innovative and reported to include social and environmental responsibility in their strategic agenda; i.e., assigned to both questions the value " 5 " (totally agree) in a 5-points Likert scale.

Since the questionnaire did not further investigate the relation between innovation and CSR, we conducted an exploratory study. In the websites of the 51 companies, 18 presented both innovations and CSR. We contacted these 18 companies, and five of them (Illustration 2) agreed to participate in the study. To preserve their anonymity, companies were named after their main activity. To assure the transparency of the data collection process, the companies' identification and contacts were provided to the editorial board of this journal. Although two companies are in a sector of low technological intensity, this does not decrease their contribution to this research, since "[...] low-tech firms, even with limited research and development capacities, can successfully innovate when they develop and use an appropriate set of capabilities" (Reichert, Torugsa, Zawislak, \& Arundel, 2016, p. 5437).

Multiple sources of evidence were sought (Eisenhardt, 1989; Yin, 2003). Company representatives were interviewed from November 2014 to January 2015. Interviews are essential for qualitative studies and recommended to understand issues involving the respondents' environment (Roesch, 2009). The interviews were carried out in person with company directors or other employees aware of the concepts investigated. A semi-structured script was drawn up, based on references on innovation and CSR, with previously defined open questions, allowing for a greater depth of answers and contingent validity (Healy \& Perry, 2000). The interviews lasted an average of one hour and were recorded and transcribed. When possible, we also conducted on-site

Revista de Gestão Social e Ambiental - RGSA, São Paulo, v. 14, n. 1, p. 93-113, jan./abr. 2020. 
visits. Interviews and on-site visits were conducted by two researchers, allowing the cases to be captured through different perspectives (Eisenhardt, 1989), and increasing the reliability of the observational evidence (Yin, 2003). We also sought secondary materials on companies' websites and the Internet before the interviews. This information was updated in 2018, to verify whether there were any additional changes. The triangulation of multiple data collection methods was sought to achieve a stronger substantiation of constructs and hypotheses (Eisenhardt, 1989; Healy \& Perry, 2000).

Illustration 2: Companies interviewed

\begin{tabular}{|c|c|c|c|c|c|c|}
\hline Company & Sector ${ }^{1}$ & Key Segments ${ }^{2}$ & $\begin{array}{l}\text { Technological } \\
\text { Intensity }\end{array}$ & $\begin{array}{l}\text { Interviewee } \\
\text { (position) }\end{array}$ & $\begin{array}{c}\text { Number of } \\
\text { collaborators }\end{array}$ & $\operatorname{Size}^{5}$ \\
\hline Chemistry & Chemicals & $\begin{array}{c}\text { Materials to } \\
\text { sanitize hospitals } \\
\text { and industries }\end{array}$ & Medium high & Buyer & 21 & Micro \\
\hline Electronics & Electronics & $\begin{array}{c}\text { Precision } \\
\text { agricultural } \\
\text { equipment and } \\
\text { devices }\end{array}$ & High tech & Director & 17 & Micro \\
\hline Footwear & $\begin{array}{l}\text { Machines } \\
\quad \text { and } \\
\text { Equipment }\end{array}$ & $\begin{array}{l}\text { Machines and } \\
\text { equipment for } \\
\text { footwear and } \\
\text { dubbing }\end{array}$ & Medium high & $\begin{array}{l}\text { Engineering } \\
\text { and quality } \\
\text { coordinator }\end{array}$ & 85 & Small \\
\hline Packaging & $\begin{array}{l}\text { Paper and } \\
\text { cellulose }\end{array}$ & $\begin{array}{l}\text { Packaging for } \\
\text { food, chemicals, } \\
\text { and seeds }\end{array}$ & Low & $\begin{array}{l}\text { Production } \\
\text { m } \\
\text { anager }\end{array}$ & 91 & Medium \\
\hline Walnut & Food & $\begin{array}{c}\text { Walnuts and } \\
\text { walnut seedlings }\end{array}$ & Low & Director & 42 & Medium \\
\hline
\end{tabular}

Data analysis was based on the content analysis technique, which includes a set of communication analysis techniques, aiming to enrich the reading of the data collected (Bardin, 2006). The technique involves three steps: (i) pre-analysis; (ii) exploration of the material; and (iii) treatment of results, inference and interpretation. The analysis was performed according to the categories found in the literature review (Illustration 3). Within-case and cross-case analysis were performed to understand specificities of each case and similarities and differences between cases, respectively (Eisenhardt, 1989).

To provide trustworthiness, a case study database was created, quotations were used in reporting results, tables summarize data, and procedures were described in detail (Eisenhardt \& Graebner, 2007; Healy \& Perry, 2000). We sought convergence on the different information collected as a basis to results and conclusions (Yin, 2003). The following section presents results according to the categories in Illustration 3.

\section{RESULTS AND DISCUSSION}

This section presents and discusses results on innovation (section 4.1), CSR (section 4.2) and the relation of the topics (section 4.3).

\subsection{Innovation}

Initial categories in the innovation analysis are types, impact and level of uniqueness. In Walnut, the innovation in the production of walnut seedlings has been key to its competitiveness, as with the covered root system and the development of genetic material that is appropriate for the 
local conditions and does not require fungicides. The sharing of knowledge with producers on cultivation and commercialization methods has encouraged an increase in the number of producers, the installation of suppliers of machinery, and the creation of a pecan nut production pole in the region. The company was also registering five product patents. Innovation in Walnut can be considered radical at the national level: "I believe that [the Walnut] company is totally innovative. We invented machines; we invented a process. In fact, we transformed a whole chain that was stagnant in Brazil" (Walnut).

In Electronics, innovations are essentially in products. The opportunities for innovation, at a national level, are related to the specificities of regional agriculture - climate, soil, and moisture. The company offers agricultural solutions based on its technology. The director explains that several projects developed have not yet been launched, because the market is not ready for them: "[...] sometimes the company needs to control its innovation to keep up with the marketplace where it is. We have some projects that we started to develop five years ago, to which we see the market is not ready yet. Maybe in two or three, or maybe five years, the market will be ready for them" (Electronics). Both radical and incremental innovations are developed, and reconciling them has been a challenge, since the former allows the company to grow, while the latter enables the consolidation in the market.

Illustration 3: Categories of analysis

\begin{tabular}{|c|c|c|}
\hline & Categories of Analysis & Authors \\
\hline \multirow{5}{*}{ Innovation } & $\begin{array}{l}\text { Types: product, process, } \\
\text { organizational, or marketing }\end{array}$ & Oecd (2005), De Jong and Marsili (2006) \\
\hline & Impact: radical or incremental & Forsman and Annala (2011) \\
\hline & $\begin{array}{l}\text { Level of uniqueness: new to } \\
\text { the company, to the market, to the } \\
\text { world }\end{array}$ & Oecd (2005) \\
\hline & Motivations for innovation & $\begin{array}{l}\text { Hernández-Espallardo and Delgado-Ballester } \\
\text { (2009), Gruenberg-Bochard and Kreis-Hoyer (2009) }\end{array}$ \\
\hline & Limiting factors & $\begin{array}{l}\text { Pavitt (1984), Hernández-Espallardo and } \\
\text { Delgado-Ballester (2009) }\end{array}$ \\
\hline \multirow{4}{*}{ CSR } & $\begin{array}{l}\text { Kind of CSR practices: social } \\
\text { and environmental }\end{array}$ & European Commission (2001) \\
\hline & $\begin{array}{l}\text { Influencing factors: size, } \\
\text { sector, legislation, leaders' and } \\
\text { members' values, concerns for the } \\
\text { reputation }\end{array}$ & $\begin{array}{l}\text { Bocquet and Mothe (2011), Murillo and Lozano } \\
\text { (2006), Vo (2011), Petrini et al. (2017) }\end{array}$ \\
\hline & $\begin{array}{l}\text { Type of CSR: responsive or } \\
\text { strategic }\end{array}$ & Porter and Kramer (2006) \\
\hline & $\begin{array}{l}\text { Strategic dimension of CSR: } \\
\text { centrality, specificity, proactivity, } \\
\text { voluntarism, visibility }\end{array}$ & Burke and Logsdon (1996) \\
\hline \multirow{4}{*}{$\begin{array}{l}\text { Innovation } \\
\text { And CSR }\end{array}$} & $\begin{array}{l}\text { CSR generating / positively } \\
\text { influencing innovation }\end{array}$ & $\begin{array}{c}\text { Stigson (2002), Hamza and Dalmarco (2013), } \\
\text { Sharma and Vredenburg (1998), Nidumolu, Prahalad, and } \\
\text { Rangaswami (2009), Bocquet et al. (2013), Porter and } \\
\text { Kramer (2006), Barakat and Polo (2016), Ratajczak and } \\
\text { Szutowski (2016), García-Piqueres and García-Ramos } \\
\text { (2020) }\end{array}$ \\
\hline & $\begin{array}{l}\text { Bidirectional relationship } \\
\text { between CSR and innovation }\end{array}$ & $\begin{array}{l}\text { Husted and Allen (2007); McWilliams and Siegel } \\
\text { (2000); Moore and Spence (2006) }\end{array}$ \\
\hline & $\begin{array}{l}\text { Factors that influence how the } \\
\text { concepts affect each other: sector, } \\
\text { company features, innovation type, } \\
\text { CSR dimension, sector, size }\end{array}$ & $\begin{array}{l}\text { Ratajczak and Szutowski (2016), García-Piqueres } \\
\text { and García-Ramos (2020), Bocquet et al. (2017), Bocquet } \\
\text { and Mothe (2011) }\end{array}$ \\
\hline & $\begin{array}{l}\text { Different results in terms of } \\
\text { innovation if the CSR is strategic or } \\
\text { responsive }\end{array}$ & $\begin{array}{l}\text { Bocquet and Mothe (2011), Bocquet et al. (2017), } \\
\text { Porter and Kramer (2006) }\end{array}$ \\
\hline
\end{tabular}

Source: Authors (2020)

Revista de Gestão Social e Ambiental - RGSA, São Paulo, v. 14, n. 1, p. 93-113, jan./abr. 2020. 
Packaging presents mainly incremental innovations in process and products. The production manager claims that the company has the best peripheral technologies and, although it does not develop new products, it improves the existing ones: "The company in this sense [of developing new products] is very conservative". The company has been improving product-related aspects, such as porosity, smoothness, and folding, to facilitate the manipulation of the paper by the machines. Its process innovations can be considered new to the company and focused on product improvements.

Footwear has innovations in products, standing out for footwear machines sold in the international market. There is a high investment in development, engineering, and changes in the working concept, which have earned them patents. Some innovations are radical, and others incremental. It is also changing the way it sells products: more than just demonstrating the equipment's operation, it also calculates the clients' possible energy savings from the company's machines.

In Chemistry, innovations are incremental and product- and process-oriented. One of the reasons for the low investment in innovations is that many customers decide their purchases based on prices. The main focus is on incremental innovations in processes that reduce costs: "Do we have product innovation? We do have. But sometimes the innovation is to generate lower [costs], it is much more an innovation of process, than of product" (Company Chemistry). The company is also transitioning from family to professional management.

Therefore, in general there are more innovations in product and processes, with fewer organizational and marketing innovations. Despite that, the proximity to customers seems essential to the innovative activity, since it allows innovations to be in line with their needs and expectations.

Regarding the impact, innovations seem mainly incremental. Electronics and Footwear, which have a full-time R\&D activity, also have radical innovations. In Walnut there are radical innovations at the national level. The level of uniqueness varies, with most innovations being new to the companies, and some new to the market.

\subsubsection{Motivations and limitations}

Innovations in the studied companies seem mainly motivated by financial gains - that can come from a better performance or from differentiation in the market. In Walnut, initial motivations for new production techniques are to improve the performance of nut seedlings, due to market competition. The limitations to innovation refer to the bureaucracy for obtaining financing, lack of public support and lack of an innovation culture among workers and partners.

In Packaging and Footwear, the motivation for innovation is also related to competitiveness and differentiation. Limitations are the high investments needed, that increase the price of the final product. For Packaging, the conservative organizational culture is another barrier.

In Electronics, the motivations are mainly related to "[...] two forces: one was the desire for entrepreneurship, the other is the identification of an opportunity in the agriculture market". De spite the demand for precise instruments in agriculture, if the introduction timing is not appropriate, the technologies may not be accepted. The constraints to innovation include the long crop cycles - that make the adoption of a technology slow - the innovation process itself and a financial and human resources restriction.

In Chemistry, the motivations for innovation comes from the customers' requests and new products launched by suppliers: "Maybe if there was no demand from the customer, there would be no innovation". The company finds it difficult to make the customer perceive the advantages of an innovative product - that is more expensive, but also more effective. Several inventions are developed, but these rarely generate financial return to the company, i.e. they do not become innovations. There is often a mismatch between what is requested by the client, what is understood by the commercial area and what is requested to the laboratory. Unlike Electronics, which tries to

Revista de Gestão Social e Ambiental - RGSA, São Paulo, v. 14, n. 1, p. 93-113, jan./abr. 2020. 
observe the maturity of the market, Chemistry develops products as they are requested by specific customers, often without previously studying market demands. Currently, not even $20 \%$ of the 400 products available are sold. Finally, the chain coordination and integration are other challenges.

Companies that have partnerships with universities and other institutions, as Walnut and Chemistry, seem to be constantly looking for improvements, mainly in products and processes. It is possible that these partnerships are stimulating the innovative attitude (Gruenberg-Bochard \& Kreis-Hoyer, 2009; Oecd, 2005), although for Chemistry it is hard to transform inventions into innovations.

With regard to differences across sectors, Electronics, which is in a high technological intensity industry, develops innovation activities closer to formal R\&D, with product development and registration of patents. The companies in sectors of medium technological intensity also have innovative activities, including the development of their own machinery for export. Walnut, in a low technological sector, can also be considered innovative. It registered five patents and restored and gave dynamism to a stagnant chain.

Therefore, even companies in low-technology sectors can be innovative and stimulate innovation in their sector (Reichert et al., 2016), or even stimulate the development of a chain in the country. This aspect strengthens evidences by Hirsch-Kreinsen (2008a, 2008b) about the inadequacy of the term "low-tech" adopted to designate certain sectors, in view of the innovativeness of these sectors and also its relevance to the industry's innovativeness.

\subsection{Corporate Social Responsibility}

Initial categories in the CSR analysis are kind of CSR practices (social and environmental) and influencing factors. In terms of environmental practices, Walnut follows guidelines for ecoefficiency: it reuses nutshells and community waste as fertilizer, uses reforestation wood and does not use pesticides. Electronics develops products with lower environmental impact by consuming fewer resources. Packaging uses water-based paints and biodegradable paper in its products, even if it is more expensive: "I have been working with this environmental part, and it is much more expensive to work with water [as a paints' base]". Footwear produces environmentally-friendly machines and reduces the consumption of electricity in its plant. Chemistry develops products that are less harmful to the environment. Electronics, Footwear, and Chemistry claim to help customers to reduce their environmental impact, and Walnut works with producers to reduce the pesticides use. All companies declared to comply with the legislation on the disposal of waste and wastewater treatment, sometimes having an effluent treatment plant, reusing water and/or having a selective garbage collection.

In summary, Electronics and Footwear focus on developing machinery and equipment that use fewer resources, generate less waste and have increased productivity. Chemistry and Packaging use inputs less harmful to the environment. Walnut uses fewer resources (or avoids the use, in the case of pesticides) and reuses materials and waste in its practices.

These environmental practices are usually motivated by opportunities of saving resources and financial outcomes: "We consider [environmental and social factors], but the main motivators of the changes are the company's financial management and health" (Electronics). As most companies follow the law, but do not go much beyond these requirements, another important motivation is to comply with the legislation, corroborating with Petrini et al. (2017), according to which legislation is an external driver to the investment in sustainability. Companies also adopt environmental practices to meet customers' demands and follow market trends: "[...] we saw that [in] the whole world, in all lectures, the strong word that came was sustainability. Companies concerned with it would have a long life; companies that didn't search that [would have a] short life" (Packaging).

Social actions mostly focus on the internal public and close community, in accordance with the literature on CSR in SMEs (Bocquet \& Mothe, 2011). Electronics does not have specific social 
actions. Chemistry delivers food and cleaning products and organizes workshops with poor communities. Packaging has internal benefits and some external practices, as helping out charities. Footwear also offers internal benefits - a gym, library, cafeteria, community center and benefit projects - that have granted it an award in 2009 as one of the " 150 Best Companies to Work For" in the country (Footwear's website). It also has campaigns with external entities. Walnut has undertaken more social actions - hiring disabled workers, assisting partner farmer families, promoting youth retention in the field, supporting recycling cooperatives and sponsoring events. The community work involves projects on music, painting, history, crafts, health and education, supported by universities and sometimes related to the business.

Regarding the influence of different factors in CSR, besides the importance of legislation, environmental practices target financial returns and social practices are mainly motivated by employees' attraction, satisfaction and retention. As in previous studies (Murillo \& Lozano, 2006; Vo, 2011), these SMEs mostly present non-formalized CSR and it is hard for them to understand how CSR generates benefits to the company - as section 4.2.1 details.

Companies' sectors influence the possible CSR practices, as stated by Bocquet and Mothe (2011) - especially in regards to the environmental ones, which are related to production practices and waste generation. Social practices are mostly philanthropic or benefiting employees, and do not vary much in the different sectors. The top management worldview, as suggested by Petrini et al. (2017), also influences the extent and nature of CSR practices.

\subsubsection{CSR dimensions and strategic types}

This section analyzes companies' CSR practices according to the strategic dimensions of Burke and Logsdon (1996). Illustration 4 summarizes practices in each dimension. Next, we discuss the type of CSR (strategic or responsive).

In centrality, no company presented a specific CSR policy. However, Walnut, Packaging and Footwear have some formal actions and guidelines: the first in a project with guidelines for ecoefficiency; the second in its quality policy; and the third in a project that encourages reduction, reuse, and recycling. Chemistry has informal CSR practices and includes environmental aspects in some decisions. Electronics has no CSR practice and is the only company that does not mention social and environmental issues in the company's goals, vision, policies, or values. The director considers that the company meets CSR by promoting food production with less resources. CSRrelated issues, therefore, are present in the director's speech, but not in the company's formal description and guidelines.

Central CSR activities in the companies mainly relate to eco-efficiency in processes or products. Only Walnut and Chemistry mentioned philanthropic activities connected to their businesses: "[since we are in this line of cleaning products], we supply products so that [nursing homes and children's homes] can clean clothes, clean floors..." (Chemistry). Walnut and Chemistry also support universities' projects related to their activities. Walnut seems to be the company in which CSR is most central: "Our DNA, our soul has this vision [of CSR]".

In specificity, Chemistry, Footwear and Walnut internalize R\&D benefits with patents. Electronics develops products with its own technology. All companies seek to internalize benefits related to reducing resources' consumption. They also provide employee benefits: "We are the only company that invested in [...] handlers [...] to avoid repetitive strain injuries for employees. And the satisfaction that this gives to people... [...] The moment a person feels more comfortable, the person will naturally do more. And the numbers are fantastic in relation to the [company's] productivity" (Packaging). Companies also have philanthropic and pollution prevention actions that contribute to the community and society, but do not generate internal benefits besides avoiding a bad reputation or punishments from the government.

Revista de Gestão Social e Ambiental - RGSA, São Paulo, v. 14, n. 1, p. 93-113, jan./abr. 2020. 
In proactivity, we found little evidence on planning and anticipation of CSR. Some companies follow sustainability trends presented in fairs (Packaging) and by experts (Walnut). Footwear and Chemistry offer superior employee benefits. In terms of environmental scanning that creates edge in products, Walnut developed production methods and genetic material that do not require agrochemicals; and Footwear provides a calculating service of the customers' potential savings: "Instead of selling, we're [...] doing a return on investment for the client. We go there, we take his process, 'well this is your current process, you're spending 'this much'. This is your new process [with Footwear's machines], you will spend 'this much'",.

In voluntarism, Electronics says it does not go beyond legal requirements: "We have some basic care with some waste that we generate, but nothing special, nothing but complying with the legislation". The other companies presented some voluntary practices - community support, donations, organizations of events and employee benefits. Chemical, for example, removed iodine from its products for the sake of employees' health: "We saw that, even though the law did not say anything, it [iodine] was bad for the employee. [...] So, we eliminated the product from the market - even though it was sold. So, we have this concern".

Many companies also stress that they follow the legislation and customers' request, especially in environmental practices, showing some decision-making is externally imposed: "I really believe that this socio-environmental issue still needs to be very much legislated for it to happen, because it is something that often does not bring financial returns. And we live in a world where we only do what brings financial returns" (Footwear). Walnut also seems to have more voluntary actions: "Long before being fashionable or legal impositions, Walnut [...] anticipated concepts with high social and environmental commitment" (Walnut's website).

In visibility, Electronics does not disclose any information on CSR-related aspects. Chemistry acknowledges that it needs to improve its actions' visibility, and hired a consultancy to that end. Footwear has actions through different internal and external channels, and was also recognized by the media for the employees' satisfaction. Packaging affirms it maintains customers' loyalty on the basis of its acknowledged environmental practices. Walnut also seems widely recognized by the internal and external public for its CSR activities.

In short, we found more evidence related to centrality, specificity and visibility; and less on proactivity and voluntarism. Despite partially covering all dimensions, there is not enough evidence to say that the companies employ a strategic CSR. They seem mostly reactive to what is done in the market, requested by customers, or imposed by law.

Walnut seems to be the company that most relates CSR to its strategy. According to its director, social and environmental practices were a part of the original business plan. The CSRrelated ideas were stimulated in courses on Marketing and Agribusiness, in which the owners learned that CSR and Social Marketing "[...] would be the future of Marketing, the future of agribusiness companies." Then the entrepreneurs "[...] started to invest in it as a mechanism to reach the European market". This example shows the importance of the top management orientation towards CSR.

In the other companies - especially Electronics - CSR seems to not be an important aspect in the strategy. The main focus is on attending the legislation (Porter \& Kramer, 2006) and capturing potential demands of society. These activities mainly influence the companies' internal image and do not generate many other advantages in strategic terms.

The companies believe their CSR practices create value, but the majority does not have a tool to measure the value created: "I believe that yes [there is a relationship between profitability and CSR], but I cannot say how much" (Packaging). Therefore, it is still necessary for them to measure and compare the value from CSR projects (Burke \& Logsdon, 1996). 
Corporate social responsibility and innovation: a multiple case study with brazilian companies

Illustration 4: Analysis of the strategic dimensions of Burke and Logsdon (1996)

\begin{tabular}{|c|c|c|c|c|c|}
\hline Dimension & Chemistry & Electronics & Footwear & Packaging & Walnut \\
\hline Centrality & $\begin{array}{l}\text { - Mission and quality policy } \\
\text { mention social and } \\
\text { environmental goals } \\
\text { - Some philanthropy related to } \\
\text { the business } \\
\text { - Some environmental } \\
\text { practices relate to the } \\
\text { business, as reduction of } \\
\text { inputs. } \\
\text { - Projects with universities }\end{array}$ & $\begin{array}{l}\text { - Company description } \\
\text { unrelated to CSR } \\
\text { - The technology developed } \\
\text { generates social and } \\
\text { environmental benefits } \\
\text { through a more efficient food } \\
\text { production (considering local } \\
\text { particularities), with fewer } \\
\text { inputs and less waste }\end{array}$ & $\begin{array}{l}\text { - Mission mentions value } \\
\text { creation to stakeholders and } \\
\text { society } \\
\text { - Sustainability as a value } \\
\text { - CSR focuses on resources } \\
\text { use and the regional } \\
\text { workforce } \\
\text { - Develop eco-friendly } \\
\text { technology that needs less } \\
\text { materials and energy }\end{array}$ & $\begin{array}{l}\text { - Policies related to CSR goals } \\
\text { - Some environmental } \\
\text { practices relate to the } \\
\text { business, social practices are } \\
\text { fundamentally philanthropic. } \\
\text { - Resource reduction } \\
\text { - Recyclable and } \\
\text { biodegradable products } \\
\text { - Employees benefits and } \\
\text { community charities }\end{array}$ & $\begin{array}{l}\text { - Company's description with } \\
\text { social and environmental } \\
\text { issues } \\
\text { - Some philanthropy related to } \\
\text { the business } \\
\text { - Central business activities } \\
\text { target CSR in both } \\
\text { environmental and social } \\
\text { aspects } \\
\text { - Projects with universities }\end{array}$ \\
\hline Specificity & $\begin{array}{l}\text { - Patents } \\
\text { - Employee benefits (food } \\
\text { basket, discounts, no extra } \\
\text { hours, safe processes and } \\
\text { materials) } \\
\text { - Material savings }\end{array}$ & $\begin{array}{l}\text { - Employee benefits (flexible } \\
\text { working hours) } \\
\text { - Products that save energy } \\
\text { and materials }\end{array}$ & $\begin{array}{l}\text { - Patents } \\
\text { - Employee benefits (gym, } \\
\text { project on reading, birthday } \\
\text { present) } \\
\text { - Technology that save energy } \\
\text { and materials }\end{array}$ & $\begin{array}{l}\text { - Employee benefits (health) } \\
\text { - Products and processes that } \\
\text { save energy and inputs }\end{array}$ & $\begin{array}{l}\text { - Patents } \\
\text { - Processes that save materials }\end{array}$ \\
\hline Proactivity & $\begin{array}{l}\text { - Hired a consultant to } \\
\text { improve employee benefits }\end{array}$ & - Not mentioned & $\begin{array}{l}\text { - Award as one of the best } \\
\text { companies to work at } \\
\text { - Customer service measuring } \\
\text { potential energy gains }\end{array}$ & $\begin{array}{l}\text { - Try to anticipate } \\
\text { sustainability trends }\end{array}$ & $\begin{array}{l}\text { - Anticipation of sustainable } \\
\text { trends } \\
\text { - Pioneering sustainable } \\
\text { production method and } \\
\text { genetic material }\end{array}$ \\
\hline Voluntarism & $\begin{array}{l}\text { - Philanthropic practices } \\
\text { - Employee benefits }\end{array}$ & $\begin{array}{l}\text { - Affirm to not go beyond the } \\
\text { legal requirements }\end{array}$ & $\begin{array}{l}\text { - Philanthropic practices } \\
\text { - Employee benefits }\end{array}$ & $\begin{array}{l}\text { - Philanthropic practices } \\
\text { - Employee benefits }\end{array}$ & $\begin{array}{l}\text { - Philanthropic practices } \\
\text { Environmental practices - } \\
\text { rainwater collection and use, } \\
\text { materials' reuse, recycled } \\
\text { materials }\end{array}$ \\
\hline Visibility & $\begin{array}{l}\text { - Unsatisfactory } \\
\text { communication. } \\
\text { - Hired a consultancy to } \\
\text { improve communication } \\
\text { - Website informs } \\
\text { environmental concerns in } \\
\text { products }\end{array}$ & $\begin{array}{l}\text { - Does not disclose } \\
\text { information on CSR }\end{array}$ & $\begin{array}{l}\text { - Company actions are } \\
\text { disclosed through the } \\
\text { website, newspapers, murals, } \\
\text { screens, meetings. } \\
\text { - Received an award as one of } \\
\text { the best companies to work } \\
\text { at }\end{array}$ & $\begin{array}{l}\text { - The environmental } \\
\text { dimension is acknowledged } \\
\text { by stakeholders, but the } \\
\text { social dimension is not } \\
\text { widely disclosed. }\end{array}$ & $\begin{array}{l}\text { - Internal and external actors } \\
\text { acknowledge CSR activities. }\end{array}$ \\
\hline
\end{tabular}

Source: Authors (2020)

Revista de Gestão Social e Ambiental - RGSA, São Paulo, v. 14, n. 1, p. 93-113, jan./abr. 2020. 

Corporate social responsibility and innovation: a multiple case study with brazilian companies

\subsection{CSR and Innovation in Brazilian companies}

Companies believe that both innovation and CSR are important. They also acknowledge that there is a greater focus on innovation: "[the company] prioritizes, or makes decisions more based on innovations than on social or environmental issues. [...] Of course, the others [CSR issues] come together, but we make decisions based on innovation, which will 'pull' the socio-environmental issue" (Footwear). Therefore, CSR is a secondary consideration in the innovation process: "first I'll think, 'ah, does this innovation have a market? [...] And can I sell this on the market? Will that suit my client? [...] Ah, it will' Okay. Second stage, 'to produce it, how do I do it?', then enters the socio-environmental part" (Chemistry).

We did not identify examples in which CSR drove innovation, although previous studies found this relation (see Illustration 3). This may be due to the reactive nature of CSR (Bocquet et al., 2013; Porter \& Kramer, 2006). It is easier for the companies to perceive the return from innovation: "We cannot make decisions based solely on environmental and social sustainability, which jeopardize the long-term sustainability of the business" (Electronics). Thus, CSR does not occupy a strategic position in inducing innovation.

CSR and innovation are also based on different motivations. CSR seeks legitimacy in terms of legislation, employees and community; innovation is driven by financial returns and influenced by internal and external factors, as public incentives and investments, consumers' acceptance, market recognition, the entrepreneur vision and innovation capabilities.

In addition, CSR is associated with long-term results: "If you just want to innovate without considering the environment, it is going to be problematic in the future. The immediacy often allows you to ignore the ecological issue, and focus only on the economic, but when you think in the medium, long term, this is not possible. [...] You have to analyze the 'thing' in a more systemic way. And when you talk about systemic, you talk about [...] the environmental issue" (Walnut). Therefore, companies recognize that CSR will be increasingly required, but their present focus remains on innovation.

Finally, a two-way relationship between CSR and innovation was not found, although some previous studies have found it (Husted \& Allen, 2007; McWilliams \& Siegel, 2000; Moore \& Spence, 2006). Despite Walnut's belief that "[...] to innovate without thinking about the environmental issue, or vice versa, doesn't work very well [...]", there is a clear major focus on innovation, as previously mentioned.

In summary, although the companies state that both innovation and CSR are important, CSR guidelines and practices cannot be considered strategic. Innovation has a priority and is recognized as a way of achieving value and competitiveness. CSR occupies a secondary position, seeming more related to the company's image. We found a unilateral relation, according to which some innovations generate CSR benefits, but CSR is not promoting innovation. CSR and innovation also existed independently from each other in these companies.

\section{FINAL REMARKS}

This research aimed to investigate how innovation and CSR relate in Brazilian companies. To that end, we conducted a multiple case study with Brazilian companies that claimed to give a high priority to innovation and CSR. Although these companies try to associate CSR to their businesses, CSR was not considered strategic for this study. Environmental practices receive more attention, since they are more easily associated with financial returns. Social practices generally refer to philanthropic programs or benefits for employees, not related to the very core business of organizations.

Despite the understanding that it is necessary to go beyond economic goals, this is still a challenge in the studied companies - as it is in the Brazilian scenario (Oliveira et al., 2018). The

Revista de Gestão Social e Ambiental - RGSA, São Paulo, v. 14, n. 1, p. 93-113, jan./abr. 2020. 
Corporate social responsibility and innovation: a multiple case study with brazilian companies

few CSR practices may be explained by the lack of government incentives (Petrini et al., 2017) and of institutionalization of socio-environmental practices, with little articulation between business, governments and civil society in Brazil (Oliveira et al., 2018). Besides, consumers do not always want to adopt sustainable behaviors (Lira, 2018).

CSR could not be perceived as an innovation source. Instead, innovations sometimes generate CSR benefits. This may be related to the reactive nature of CSR in the companies. It is difficult for them to create value from CSR, since they often focus on complying with the legislation or invest in philanthropic projects. In a macro perspective, the Brazilian market may also present barriers to CSR, since CSR practices are not very much valued in relation to the price. Companies interacting with foreign markets may be required to invest more in CSR. Future studies are suggested to investigate obstacles to CSR and possibilities to overcome them.

The main contribution of this paper is to provide empirical evidence on the relation between CSR and innovation in the Brazilian context. In the cases studied, the relation found is that innovation can be a source of CSR benefits. Factors that seem to influence this relation are whether CSR is strategic of responsive, the sector and the managerial orientation. Future studies can investigate whether these aspects are confirmed with a larger sample of companies, or test the relation between CSR and innovation in specific sectors.

In terms of practical contributions, the study points to the need of investing more practices related to the strategic dimensions of proactivity and voluntarism. Besides, as companies show little knowledge on how CSR impacts the company, it becomes essential to develop appropriate methodologies for the measurement of the benefits from CSR. This could be promoted by the government or by institutions that support SMEs in the paths towards a more strategic and proactive stance in terms of CSR.

Finally, the study underlines the role of the legislation in promoting environmental actions in the Brazilian context. Policies as the National Solid Waste Policy (Política Nacional dos Resíduos Sólidos (Pnrs) (Faria, 2012) have probably enforced some of the initiatives of the companies studied. Similar policies could be useful to promote more environmental practices in the country.

\section{REFERENCES}

Banco Nacional de Desenvolvimento Econômico e Social (Bndes). (2011). Circularn ${ }^{o}$ 34, de 06 de setembro de 2011. Retrieved from:

$<$ http://www.bndes.gov.br/SiteBNDES/export/sites/default/bndes_pt/Galerias/Arquivos/produtos/do wnload/Circ034_11.pdf $>$. Access: 09 jan. 2020.

Barakat, S. R., \& Polo, E. F. (2016). Implicações estratégicas da responsabilidade social corporativa. Revista de Gestao Social e Ambiental, 10(2), 37-52.

Bardin, L. (2006). Análise de conteúdo. Lisboa: Edições 70.

Battisti, M., \& Perry, M. (2011). Walking the talk? Environmental responsibility from the perspective of small-business owners. Corporate Social Responsibility and Environmental Management, 18(3), 172-185.

Bocquet, R., Le Bas, C., Mothe, C., \& Poussing, N. (2013). Are firms with different CSR profiles equally innovative? Empirical analysis with survey data. European Management Journal, 31(6), 642-654.

Bocquet, R., Le Bas, C., Mothe, C., \& Poussing, N. (2017). CSR, innovation, and firm performance in sluggish growth contexts: a firm-level empirical analysis. Journal of Business Ethics, 146(1), $241-254$.

Revista de Gestão Social e Ambiental - RGSA, São Paulo, v. 14, n. 1, p. 93-113, jan./abr. 2020. 
Natália Rohenkohl do Canto, Andréia Cristina Dullius Verschoore, Patrícia Dias, Marcia Dutra de Barcellos

Bocquet, R., \& Mothe, C. (2011). Exploring the relationship between CSR and innovation: a comparison between small and large-sized French companies. Revue Sciences de Gestion, 80, 101120.

Burke, L., \& Logsdon, J. M. (1996). How corporate social responsibility pays off. Long Range Planning, 29(4), 495-502.

De Jong, J. P. J., \& Marsili, O. (2006). The fruit flies of innovations: a taxonomy of innovative small firms. Research Policy, 35(2), 213-229.

Eisenhardt, K. M. (1989). Building theories from case study research. Academy of Management Review, 14(4), 532-550.

Eisenhardt, K. M., \& Graebner, M. E. (2007). Theory building from cases: opportunities and challenges. Academy of Management Journal, 50(1), 25-32.

European Commission. (2001). Green paper: promoting a european framework for Corporate Social Responsibility. Brussels.

European Commission. (2011). Towards a greater understanding of the changing role of business in society. Brussels.

Faria, C. R. S. M. (2012). Boletim do Legislativo $N^{o}$ 15, de 2012: a Política Nacional de Resíduos Sólidos. Brasília. Retrieved from: <https://livroaberto.ibict.br/bitstream/1/579/1/BOLETIM DO LEGISLATIVO N N $^{0}$ 15\%2C DE 2012 a politica nacional.pdf $>$. Access: 1 jun 2020.

Federação das Indústrias do Estado do Rio Grande do Sul (Fiergs). (2013). Cadastro das Indústrias, Fornecedores e Serviços. Porto Alegre: Editora Brasileira de Guias Especiais.

Forsman, H. (2011). Innovation capacity and innovation development in small enterprises. A comparison between the manufacturing and service sectors. Research Policy, 40(5), 739-750.

Forsman, H., \& Annala, U. (2011). Small enterprises as innovators: shift from a low performer to a high performer. International Journal of Technology Management, 56(2/3/4), 154-171.

García-Piqueres, G., \& García-Ramos, R. (2020). Is the corporate social responsibility-innovation link homogeneous?: Looking for sustainable innovation in the Spanish context. Corporate Social Responsibility and Environmental Management, 27(2), 803-814.

Gruenberg-Bochard, J., \& Kreis-Hoyer, P. (2009). Knowledge-networking capability in German SMEs: a model for empirical investigation. International Journal of Technology Management, 45(3/4), 364.

Hamza, K. M., \& Dalmarco, D. de A. S. (2013). Integração entre estratégia competitiva e práticas de responsabilidade social corporativa: um estudo exploratório nos cinco maiores supermercados brasileiros. Revista de Gestão Social e Ambiental, 6(3), 78-95.

Healy, M., \& Perry, C. (2000). Comprehensive criteria to judge validity and reliability of qualitative research within the realism paradigm. Qualitative Market Research: An International Journal, 3(3), $118-126$.

Hernández-Espallardo, M., \& Delgado-Ballester, E. (2009). Product innovation in small manufacturers, market orientation and the industrýs five competitive forces. European Journal of Innovation Management, 12(4), 470-491.

Hirsch-Kreinsen, H. (2008a). “Low-Tech” Innovations. Industry and Innovation, 15(1), 19-43.

Hirsch-Kreinsen, H. (2008b). "Low-technology": a forgotten sector in innovation policy. Journal of Technology Management and Innovation, 3(3), 11-20.

Revista de Gestão Social e Ambiental - RGSA, São Paulo, v. 14, n. 1, p. 93-113, jan./abr. 2020. 
Husted, B. W., \& Allen, D. B. (2007). Corporate social strategy in multinational enterprises: Antecedents and value creation. Journal of Business Ethics, 74(4), 345-361.

International Organization for Standardization (ISO). (2010). ISO 26000:2010(en) Guidance on social responsibility. Retrieved May 20, 2020, from

https://www.iso.org/obp/ui/\#iso:std:iso:26000:ed-1:v1:en

Lira, F. T. (2018). Fatores que influenciam a valorização de produtos ecológicos por consumidores ecologicamente conscientes. Revista de Gestão Social e Ambiental, 12(2), 90-107.

McWilliams, A., \& Siegel, D. (2000). Corporate social responsibility and financial performance: correlation or misspecification? Strategic Management Journal, 21(5), 603-609.

Moore, G., \& Spence, L. (2006). Editorial: responsibility and small business. Journal of Business Ethics, 67(3), 219-226.

Murillo, D., \& Lozano, J. M. (2006). SMEs and CSR: an approach to CSR in their own words. Journal of Business Ethics, 67(3), 227-240.

Nidumolu, R., Prahalad, C. K., \& Rangaswami, M. R. (2009). Why sustainability is now the key driver of innovation. Harvard Business Review, (September), 57-64.

Organisation for Economic Co-operation and Development. (Oecd). (2005). Oslo manual: Proposed guidelines for collecting and interpreting technological innovation data. European Commission.

Oecd. (2011). Technology intensity definition. Isic rev. 3. Retrieved from: $<$ http://www.oecd.org/dataoecd/43/41/48350231.pdf >. Access: 10 fev. 2020.

Oliveira, V. M., Gomez, C. R., \& Correia, S. É. N. (2018). Papéis das empresas e o consumo sustentável na visão de especialistas brasileiros. Revista de Gestão Social e Ambiental, 12(2), 5570 .

Pavitt, K. (1984). Sectoral patterns of technical change: towards a taxonomy and a theory. Research Policy, 13(6), 343-373.

Petrini, M., Back, L. S., \& dos Santos, A. C. M. Z. (2017). Which factors drive sustainability initiatives in small and medium-sized enterprises? a multiple-case study in the leather-footwear industry in Brazil. Revista de Gestao Social e Ambiental, 11(3), 21-36.

Porter, M. E., \& Kramer, M. R. (2006). The link between competitive advantage and corporate social responsibility. Harvard Business Review, 84(12), 78-92.

Ratajczak, P., \& Szutowski, D. (2016). Exploring the relationship between CSR and innovation. Sustainability Accounting, Management and Policy Journal, 7(2), 295-318.

Reichert, F. M., Torugsa, N. A., Zawislak, P. A., \& Arundel, A. (2016). Exploring innovation success recipes in low-technology firms using fuzzy-set QCA. Journal of Business Research, 69(11), 5437-5441.

Roesch, S. M. A. (2009). Projetos de estágio e de pesquisa em administração: guia para estágios, trabalhos de conclusão, dissertações e estudos de caso. (3rd ed.). São Paulo: Atlas.

Sharma, S., \& Vredenburg, H. (1998). Proactive corporate environmental strategy and the development of competitively valuable organizational capabilities. Strategic Management Journal, 19(8), 729-753.

Stigson, B. (2002). Pillars of change. Forum for Applied Research and Public Policy, 16(4), 23-27.

Vo, L. C. (2011). Corporate social responsibility and SMEs: a literature review and agenda for future research. Problems and Perspectives in Management, 9(4), 89-97. 
Natália Rohenkohl do Canto, Andréia Cristina Dullius Verschoore, Patrícia Dias, Marcia Dutra de Barcellos

Wang, H., Tong, L., Takeuchi, R., \& George, G. (2016). Corporate social responsibility: an overview and new research directions. Academy of Management Journal, 59(2), 534-544.

Yin, R. K. (2003). Case study research: design and methods (3rd ed.). Thousand Oaks: Sage Publications. 